\title{
Integrasi concise learning method dengan mind mapping dalam pembelajaran matematika di perguruan tinggi
}

\author{
Ciptianingsari Ayu Vitantri ${ }^{1}$
}

\begin{abstract}
Abstrak: Penelitian ini bertujuan untuk mendeskripsikan penerapan, pemahaman konsep, dan respon mahasiswa terhadap pembelajaran CLM yang diintegrasikan dengan mind mapping pada mata kuliah aljabar linier elementer I. Penelitian ini termasuk dalam penelitian deskriptif kualitatif, dengan subjek penelitian adalah mahasiswa prodi matematika dan pendidikan matematika semester gasal tahun ajaran 2016/2017 yang mengambil mata kuliah aljabar linier elementer I. Instrumen utama dalam penelitian ini adalah peneliti sendiri dengan instrumen pendukung yaitu lembar observasi, tes pemahaman konsep, angket respon, dan pedoman wawancara. Hasil penelitian menunjukkan: 1) Langkah-langkah pembelajaran CLM yang diintegrasikan dengan mind mapping meliputi preview, participate, process (mengolah informasi dalam bentuk mind mapping), practice, dan produce. 2) Pemahaman konsep mahasiswa mengalami peningkatan setelah pembelajaran. Dan 3) Mahasiswa memberikan respon positif terhadap pelaksanaan pembelajaran CLM yang diintegrasikan dengan mind mapping.
\end{abstract}

Kata kunci: Concise Learning Method; Mind Mapping; Pemahaman Konsep; Respon; Aljabar Linier Elementer.

Abstract: This research aimed to describe the implementation, students' understanding and their responses on CLM integrated with mind mapping on Linear Elementary Algebra I course, This research was qualitative descriptive research with the subjects involved were students of mathematics and mathematics education on 2016/2017 academic year who took Linear Elementary Algebra I course. The main instrument in this research was the researcher and the supporting instruments used are observation sheet, test, response questionnaire, and interview guide. The results showed that: 1) The steps of CLM integrated with mind mapping include preview, participate, process (process all information into mind mapping), practice, and produce. 2) The students' understanding of the mathematics concept of were developed. And 3) the students responded positively to the

\footnotetext{
1 Universitas Pesantren Tinggi Darul 'Ulum (Unipdu), Jombang, Indonesia, ciptianingsariayu@mipa.unipdu.ac.id
} 
implementation of CLM integrated with mind mapping by showing enjoyment in the course.

Keywords: Concise Learning Method; Mind Mapping; Understanding of Concept; Responses; Linear Elementary Algebra.

\section{A. Pendahuluan}

Aljabar termasuk dalam materi yang ditakuti oleh peserta didik. Dalam kurikulum matematika, aljabar mendapat perhatian secara luas sebagai materi paling sulit dibandingkan materi matematika lainnya (Jupri, Drijvers \& Heuvel-Panhuizen, 2014). Dalam kurikulum tingkat perguruan tinggi khususnya di FMIPA Unipdu, ada beberapa mata kuliah yang termasuk dalam bagian aljabar, salah satunya adalah aljabar linier elementer I. Aljabar linier elementer I termasuk dalam mata kuliah wajib program studi (prodi) yang diajarkan pada mahasiswa tingkat awal, baik mahasiswa prodi matematika maupun pendidikan matematika.

Materi dalam mata kuliah ini menjadi prasyarat bagi mata kuliah lain. Berdasarkan buku pedoman akademik FMIPA Unipdu Jombang (Tim Kurikulum, 2015) materi yang dipelajari pada mata kuliah aljabar linier elementer I yaitu sistem persamaan linier, operasi baris elementer, eliminasi Gauss, eliminasi Gauss Jordan, sistem persamaan linier homogen, matriks, determinan matriks, invers matriks, fungsi determinan, ekspansi kofaktor dan aturan Cramer. Capaian pembelajaran yang diharapkan pada mata kuliah ini adalah mahasiswa dapat menggunakan konsep sistem persamaan linear, Operasi Baris Elementer (OBE), matriks dan determinan dalam pemecahan masalah serta terampil melakukan langkah-langkah penyelesaiannya secara teliti, mandiri dan tanggung jawab.

Pemahaman dan penguasaan yang baik terhadap konsep materi aljabar linier elementer I akan membantu mahasiswa dalam mencapai setiap capaian pembelajaran yang diharapkan. Tetapi, pada kenyataannya masih ada mahasiswa yang belum memahami konsep materi aljabar linier elementer I dengan baik. Hal ini sejalan dengan hasil penelitian Nursuprianah dan Sholikhah (2009) bahwa mahasiswa mengalami kesulitan selama mengikuti mata kuliah aljabar matriks. Kesulitan tersebut meliputi kesulitan dalam mengerjakan soal-soal pembuktian, memahami 
konsep variabel dan ketelitian dalam menyelesaikan operasi baris elementer menggunakan eliminasi Gauss Jordan. Penelitian Rosita, Laelasari, dan Noto (2014) menunjukkan bahwa pada Tes Kemampuan Pemahaman Matematis (TKPM) mata kuliah Aljabar Linier 1, secara klasikal mahasiswa tidak mencapai ketuntasan. Studi pendahuluan yang dilakukan oleh Apriyani (2015) juga menunjukkan bahwa 54.62\% mahasiswa mendapatkan nilai $D$ atau tidak lulus dalam mata kuliah aljabar linier.

Berdasarkan pengalaman peneliti sebagai dosen pengampu mata kuliah ini, penyebab mahasiswa mengalami kesulitan dalam memahami konsep karena mayoritas mahasiswa belum bisa mengaitkan konsepkonsep dalam materi, sehingga ketika membahas konsep baru banyak mahasiswa yang sudah lupa konsep lama, padahal konsep-konsep materi dalam mata kuliah aljabar linier elementer I saling berkaitan. Contohnya, ketika membahas materi penyelesaian Sistem Persamaan Linier Homogen (SPLH), mahasiswa masih mengalami kesulitan. Mahasiswa lupa konsep Operasi Baris Elementer (OBE), Eliminasi Gauss dan Eliminasi Gauss Jordan dimana konsep tersebut sebenarnya sudah dipelajari ketika membahas penyelesaian untuk Sistem Persamaan Linier (SPL). Hal ini mengakibatkan dosen harus mengingatkan kembali konsep materi yang lama dan menyita waktu perkuliahan. Karena keterbatasan waktu yang tersedia menyebabkan masih ada materi yang dalam pembahasannnya terlewati atau tidak dibahas secara mendalam.

Permasalahan lain adalah kemampuan mahasiswa di FMIPA Unipdu sangat heterogen sehingga dalam perkuliahan, dosen harus memikirkan suatu cara agar materi juga dapat terserap dengan baik oleh mahasiswa dengan kemampuan yang rendah. Selain itu, kendala lain adalah karena mata kuliah ini diberikan pada semester satu, banyak mahasiswa merasa belum siap ketika menghadapi peralihan dalam proses pembelajaran dari Sekolah Menengah ke Perguruan Tinggi. Peralihan ini terkait perubahan gaya belajar, kondisi lingkungan, tekanan tugas, tekanan lingkungan dan aspek psikologis lainnya.

Berdasarkan permasalahan di atas, maka diperlukan suatu pembelajaran yang efektif dan efisien, pembelajaran yang bermakna, dimana mahasiswa merasa terhubung dalam pembelajaran, termotivasi dalam pembelajaran, dan pada akhirnya memahami materi pembelajaran. 
Pembelajaran yang tidak hanya efektif dan efisien bagi mahasiswa dengan kemampuan tinggi tetapi juga efektif dan efisien bagi mahasiswa dengan kemampuan rendah. Salah satu pembelajaran yang memenuhi kriteria tersebut adalah CLM (Concise Learning Method). Hal ini sesuai dengan pendapat Krasnic (2011a) bahwa CLM merupakan pembelajaran yang efektif dan efisien dengan pendekatan visual, fleksibel, bermakna dan sistematis melalui pelibatan proses kognitif, aktif, konstruktif dan berbasis inkuiri.

CLM merupakan pembelajaran yang cocok diterapkan di Perguruan Tinggi, mudah digunakan dan sistematis (Krasnic, 2011b). CLM pertama kali dikembangkan oleh Toni Krasnic. CLM awalnya merupakan metode belajar yang digunakan Toni Krasnic selama menjadi mahasiswa dalam menempuh perkuliahan di Zicklin School of Business tahun 2001-2003. Metode ini kemudian dikembangkan menjadi metode pembelajaran dalam perkuliahan di bidang kimia. Tahapan dalam CLM meliputi preview, participate, process, practice, dan produce. Berikut bagan tahapan CLM (http://www.conciselearning.com/howtolearn.html).

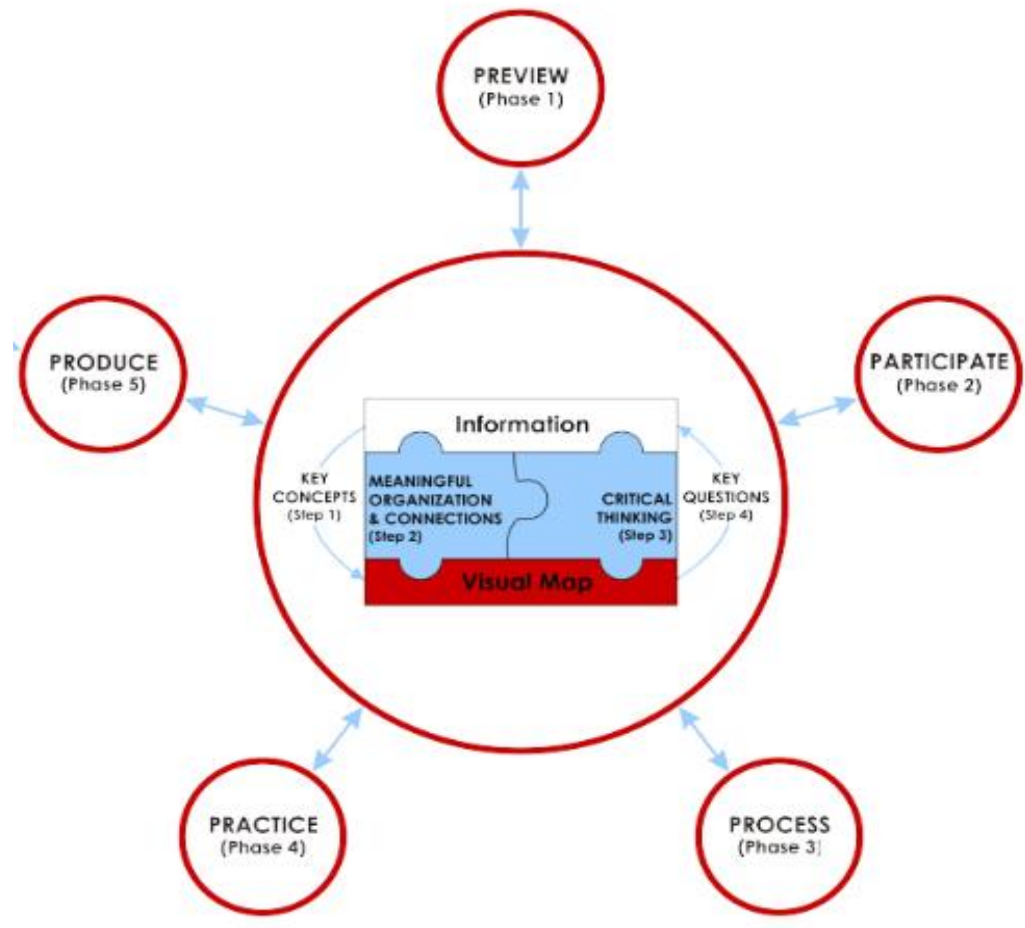

Gambar 1. Tahapan CLM 
Dalam proses perancangan penelitian, peneliti telah mencari hasil penelitian dalam bentuk jurnal atau publikasi lainnya di beberapa database online seperti google scholar terkait penerapan CLM dalam pembelajaran matematika namun belum menemukan hasil yang relevan. Hal ini menunjukkan bahwa penilitian ini mengawali penerapan CLM dalam pembelajaran matematika di perguruan tinggi. Penelitian ini mengintegrasikan CLM dengan mind mapping. Mind mapping yang dimaksud dalam penelitian ini adalah suatu metode belajar bagi mahasiswa dimana mahasiswa membuat jaringan konsep atau grafik yang menggambarkan keterkaitan antar konsep dalam materi perkuliahan. Hal ini sebagaimana yang dikemukakan Buzan dan Buzan (1994) bahwa mind mapping merupakan representasi visual dari konsep dan keterkaitannya.

Hasil penelitian Brinkmann (2003b) menunjukkan bahwa mind mapping merupakan alat yang efisien untuk meningkatkan pencapaian dalam matematika. Mustangin dan Debora (2009) menyatakan bahwa peran mind mapping dalam pembelajaran matematika sangat penting, karena matematika sebagai jaringan konsep memuat konsep-konsep yang saling berkaitan dan memiliki hubungan sebab-akibat. Hal ini sejalan dengan hasil penelitian Velasco dan Joaquin (2015) yang menunjukkan bahwa ketika peserta didik membuat mind mapping, mereka mampu mengekspresikan ide mereka, menghubungkan topik yang baru dipelajari dengan topik yang telah dipelajari sebelumnya, dan mengorganisasikan pikiran mereka.

Mind mapping diharapkan dapat membantu mahasiswa mengaitkan konsep-konsep dalam materi aljabar linier elementer I sehingga dapat meningkatkan pemahaman dan daya ingat mahasiswa. Integrasi mind mapping dalam CLM dilakukan pada tahap ketiga CLM yaitu process, dimana mahasiswa diminta untuk mengolah informasi terkait materi perkuliahan dalam bentuk mind mapping. Walaupun di dalam CLM sendiri sudah memuat visual mapping, tetapi dalam penelitian ini peneliti mengintegrasikan CLM dengan mind mapping karena mind mapping dalam pembelajaran matematika mendukung capaian pembelajaran peserta didik (Mustangin \& Debora, 2009; Velasco \& Joaquin, 2015).

Berdasarkan permasalahan di atas, maka peneliti tertarik untuk meneliti integrasi CLM dengan mind mapping pada mata kuliah aljabar linier elementer I. Penelitian ini bertujuan untuk mendeskripsikan tahapan 
pelaksanaan CLM yang diintegrasikan dengan mind mapping, mendeskripsikan pemahaman konsep mahasiswa dalam pembelajaran, dan mendeskripsikan respon mahasiswa terhadap pelaksanaan CLM terintegrasi mind mapping.

\section{B. Metode Penelitian}

Penelitian ini merupakan penelitian deskriptif. Marsigit (2012) mengungkapkan bahwa penelitian deskriptif merupakan penelitian yang bertujuan untuk mendeskripsikan situasi-situasi dan kejadian-kejadian. Hal ini sesuai dengan tujuan dalam penelitian ini yaitu mendeskripsikan penerapan CLM yang diintegrasikan dengan mind mapping pada mata kuliah aljabar linier elementer I, mendeskripsikan kemampuan pemahaman konsep mahasiswa, dan mendeskripsikan respon mahasiswa terhadap pelaksanaannya. Penelitian ini dilakukan selama satu semester dengan 16 mahasiswa prodi matematika dan pendidikan matematika FMIPA Unipdu Jombang semester gasal tahun ajaran 2016/2017 yang mengambil mata kuliah aljabar linier elementer I.

Pengumpulan data dalam penelitian ini menggunakan lembar observasi, tes pemahaman konsep, angket respon dan pedoman wawancara. Dalam penelitian ini, aspek pemahaman konsep diukur melalui beberapa indikator yaitu menyatakan ulang konsep yang telah dipelajari, mengklasifikasikan objek-objek, menerapkan konsep secara algoritma, memberikan contoh dan bukan contoh dari suatu konsep (NCTM, 2000). Sedangkan lembar observasi digunakan untuk menggali informasi terkait keterlaksanaan tahapan pembelajaran dalam CLM yang diintegrasikan dengan mind mapping (Tabel 1).

Tabel 1. Kisi-kisi Lembar Observasi

\begin{tabular}{|c|l|}
\hline No. & \multicolumn{1}{|c|}{ Aspek yang Diamati } \\
\hline 1 & $\begin{array}{l}\text { Preview: mahasiswa mempelajari terlebih dahulu materi } \\
\text { perkuliahan dan mengerjakan minimal tiga soal dan membuat } \\
\text { minimal satu pertanyaan terkait materi di buku tugas. }\end{array}$ \\
\hline 2 & $\begin{array}{l}\text { Participate: mahasiswa berpartisipasi secara aktif dalam } \\
\text { perkuliahan baik dalam diskusi kelompok maupun diskusi kelas. }\end{array}$ \\
\hline 3 & $\begin{array}{l}\text { Process: mahasiswa mengolah informasi terkait materi perkuliahan } \\
\text { dalam bentuk mind mapping. }\end{array}$ \\
\hline 4 & $\begin{array}{l}\text { Practice: mahasiswa mengerjakan soal-soal baik soal latihan di buku } \\
\text { atau soal yang diajukan oleh temannya. }\end{array}$ \\
\hline 5 & Produce: mahasiswa menghasilkan ide baru. \\
\hline
\end{tabular}


Angket respon mahasiswa digunakan untuk menggali pendapat mahasiswa terkait penerapan CLM yang diintegrasikan dengan mind mapping, kemampuan pemahaman konsep mahasiswa dan meminta saran untuk perbaikan pembelajaran selanjutnya. Berikut kisi-kisi angket respon mahasiswa.

Tabel 2. Kisi-kisi Angket Respon Mahasiswa

\begin{tabular}{|c|l|}
\hline No. & \multicolumn{1}{|c|}{ Aspek } \\
\hline 1 & $\begin{array}{l}\text { Ketertarikan terhadap pelaksanaan pembelajaran CLM yang } \\
\text { meliputi tahap: Preview, Participate, Process, Practice, dan Produce }\end{array}$ \\
\hline 2 & $\begin{array}{l}\text { Pembuatan mind mapping dan manfaat menggunakan mind } \\
\text { mapping dalam belajar }\end{array}$ \\
\hline 3 & Kemampuan pemahaman konsep mahasiswa \\
\hline 4 & $\begin{array}{l}\text { Saran terhadap pembelajaran CLM yang diintegrasikan dengan } \\
\text { mind mapping untuk selanjutnya. }\end{array}$ \\
\hline
\end{tabular}

Data dalam penelitian ini berbentuk verbal (kata-kata) yang meliputi deskripsi hasil observasi pembelajaran, deskripsi hasil tes pemahaman konsep mahasiswa, deskripsi hasil angket respon mahasiswa dan deskripsi hasil wawancara dengan mahasiswa. Data yang diperoleh kemudian dianalisis menggunakan model interactive model, yang meliputi data reduction (reduksi data), data display (penyajian data), dan conclusions drowing/verifiying (penarikan kesimpulan/verifikasi). Berikut alur analisis data dalam penelitian ini (Spradley, 2007).

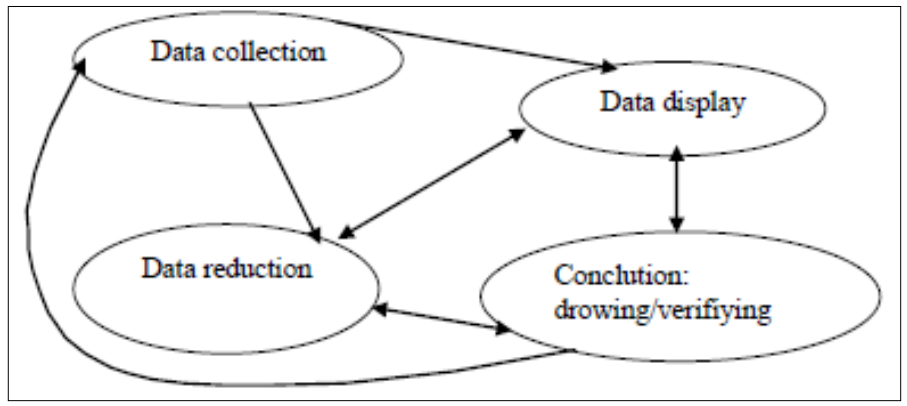

Gambar 2. Teknik Analisis Data (Interactive model) 


\section{Temuan dan Pembahasan}

\section{Pelaksanaan CLM dengan mind mapping}

Pembelajaran Concise Learning Method (CLM) yang diintegrasikan dengan mind mapping pada penelitian ini dilaksanakan selama satu semester. Hasil observasi secara keseluruhan terhadap pelaksanaan pembelajaran CLM dengan mind mapping pada mata kuliah aljabar linier elementer I berjalan sesuai dengan tahapan CLM. Pada pertemuan pertama dosen menyampaikan silabus dan kontrak perkuliahan, kemudian dilanjutkan dengan pengantar ke materi Sistem Persamaan Linier (SPL). Pada pertemuan ini, juga dilakukan tahap pertama dari CLM yaitu preview, dimana pada akhir perkuliahan untuk pertemuan pertama dosen menginformasikan kepada mahasiswa terkait materi yang akan dipelajari pada pertemuan berikutnya. Mahasiswa diminta untuk mempelajari terlebih dahulu materi dan mengerjakan minimal tiga soal serta membuat minimal satu pertanyaan terkait materi. Pertanyaan dan hasil kerja mahasiswa ditulis di dalam buku tugas. Pada pertemuan berikutnya, mahasiswa terbukti telah mempelajari materi sebelumnya, hal ini terlihat dari kualitas pertanyaan yang diajukan dan soal-soal yang dikerjakan di buku tugas.

Pada tahap kedua CLM yaitu participate, dosen mendorong mahasiswa terlibat secara aktif selama perkuliahan. Hal ini dilakukan dengan cara membagi mahasiswa menjadi beberapa kelompok, dimana setiap kelompok beranggotakan dua orang (pembentukan kelompok dilakukan pada pertemuan pertama ketika penyampaian kontrak kuliah). Kemudian dosen menunjuk secara acak salah satu kelompok untuk mempresentasikan materi di depan kelas, sedangkan kelompok yang lain diminta untuk memperhatikan dengan seksama dan mencatat jika ada hal-hal yang ingin ditanyakan terkait penjelasan kelompok yang maju karena setelah presentasi selesai, dosen mewajibkan setiap kelompok untuk mengajukan pendapat, sanggahan atau pertanyaan terkait materi yang disampaikan.

Dari keseluruhan tahapan pada CLM, tahap satu (preview) dan dua (participate) tidak ada kendala yang berarti, sedangkan pada tahap tiga yaitu process, mind mapping yang dibuat mahasiswa masih perlu diperbaiki lagi karena masih ada beberapa konsep materi yang masih salah. Berikut salah satu mind mapping yang dibuat oleh mahasiswa. 


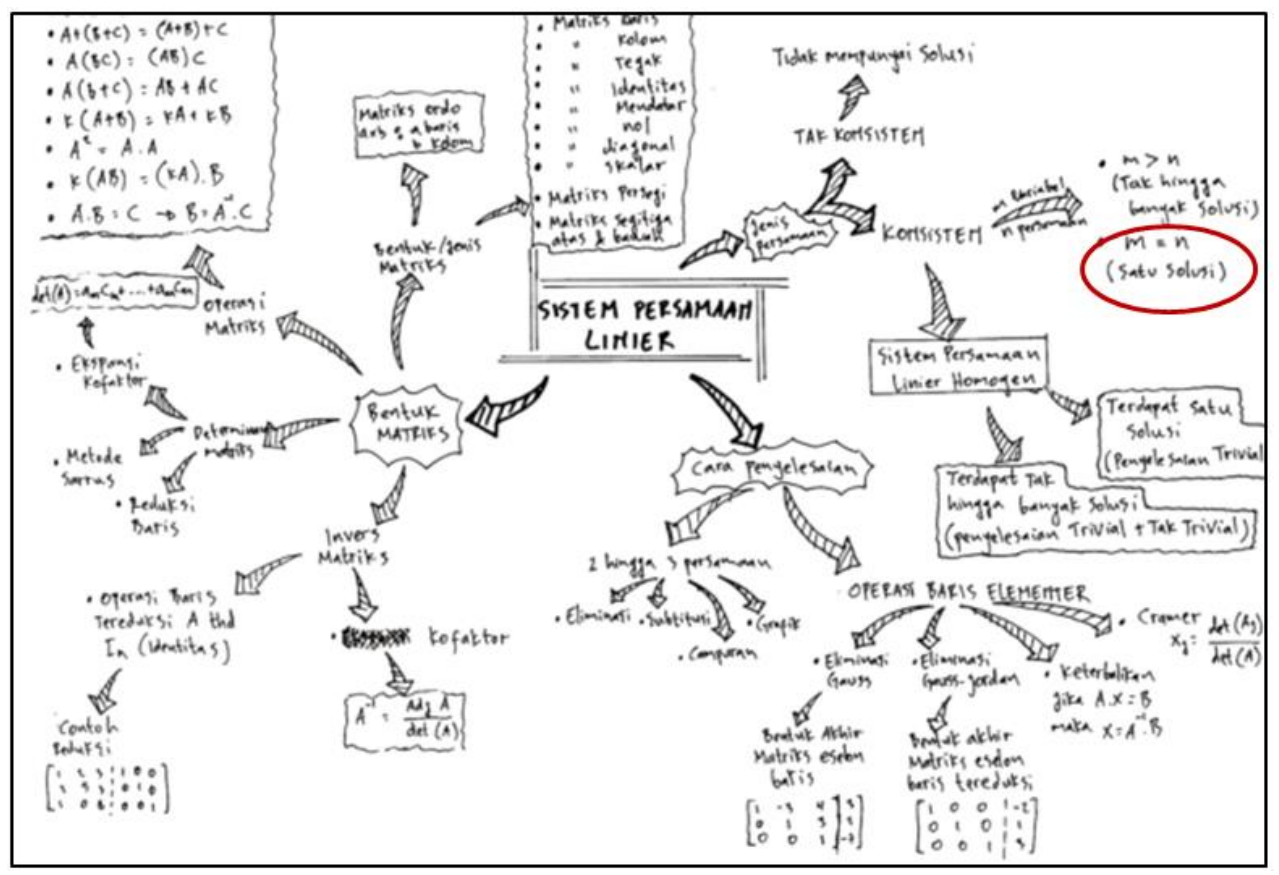

Gambar 3. Salah satu mind mapping yang dibuat mahasiswa

Dari mind mapping yang dibuat mahasiswa pada Gambar 3 (yang dilingkari merah) terlihat bahwa untuk Sistem Persamaan Linier (SPL) dengan banyaknya variabel sama dengan banyaknya persamaan, mahasiswa menuliskan bahwa SPL tersebut mempunyai satu solusi, padahal yang benar adalah ada tiga kemungkinan solusi dari SPL tersebut yaitu satu solusi, tak hingga banyaknya solusi atau tidak ada solusi.

Pada tahap keempat dari CLM yaitu practice, mahasiswa diminta untuk sering berlatih menyelesaikan soal. Soal-soal yang dikerjakan sebagian besar berasal dari buku pegangan mata kuliah. Cara yang digunakan dosen untuk mendorong mahasiswa aktif dalam berlatih menyelesaikan soal adalah dengan sering memberi soal setiap penyampaian materi sudah selesai, baik melalui tanya jawab langsung secara bergiliran atau diberikan sebagai pekerjaan rumah. Pada tahap ini, dosen juga mengingatkan mahasiswa agar tidak hanya membaca contoh soal yang solusinya sudah disediakan dan hanya menyelesaikan masalah yang sama dengan contoh yang disediakan, tetapi lebih dari itu mahasiswa diminta untuk menerapkan materi yang sudah dipelajari dalam 
masalah yang baru (soal yang tidak diprediksi sebelumnya). Salah satu masalah yang tidak diprediksi oleh mahasiswa sebelumnya adalah soalsoal ON MIPA PT. Soal-soal ON MIPA PT yang diambil adalah soal-soal yang ada hubungannya dengan materi yang dipelajari. Berikut salah satu soal ON MIPA PT tahun 2011 yang diberikan kepada mahasiswa.

Misalkan $A=\left[a_{i j}\right]$ matriks berukuran $2011 \times 2011$ dengan

$$
a_{i j}= \begin{cases}(-1)^{|i-j|} & \text { jika } i \neq j \\ 2 & \text { jika } i=j .\end{cases}
$$

Tentukan $\operatorname{det}(A)$

Gambar 4. Salah Satu Soal ON MIPA PT Tahun 2011 yang Diberikan Dosen

Dari 16 mahasiswa yang mengerjakan soal tersebut, tiga mahasiswa sudah bisa menjawab meskipun belum menemukan hasil akhirnya, sedangkan yang lain masih bingung dengan maksud soalnya. Dalam hal ini, dosen memberikan arahan sehingga mahasiswa menemukan sendiri jawaban dari soal tersebut. Arahan dosen kepada mahasiswa ini seperti meminta mahasiswa untuk memperhatikan kembali bentuk matriks dan meminta untuk menuliskan entri matriks tersebut sesuai dengan ketentuan yang ada di soal. Setelah itu, mahasiswa diingatkan kembali cara-cara dalam menentukan determinan matriks. Kemudian dari caracara tersebut, mahasiswa diminta untuk memilih cara yang sesuai untuk digunakan dalam menyelesaikan soal tersebut.

Pada tahap kelima yaitu produce, dari 16 mahasiswa hanya dua mahasiswa yang bisa menghasilkan ide baru. Ide baru yang dihasilkan mahasiswa yaitu ketika melakukan reduksi baris, mahasiswa dapat melakukan beberapa kali Operasi Baris Elementer (OBE) dalam sekali mereduksi matriks. Ide baru yang lain yaitu terkait kemungkinan solusi dari Sistem Persamaan Linier (SPL), dimana di dalam buku pegangan mata kuliah aljabar linier elementer I hanya dibahas solusi untuk SPL dengan banyaknya persamaan sama dengan banyaknya variabel, dan banyaknya persamaan lebih sedikit dari banyaknya variabel. Sementara untuk SPL dengan banyaknya persamaan lebih banyak dari banyaknya variabel tidak dibahas. Dalam pembelajaran, mahasiswa menemukan bahwa ketika banyaknya persamaan SPL lebih banyak dari banyaknya variabel 
kemungkinan solusi SPL tersebut sama halnya dengan ketika banyaknya persamaan SPL sama dengan banyaknya variabel yaitu ada tiga kemungkinan solusi (satu solusi, tak hingga banyaknya solusi dan tidak ada solusi).

\section{Pemahaman konsep mahasiswa setelah penerapan Concise Learning Method (CLM) dengan mind mapping}

Pemahaman konsep mahasiswa dapat dilihat dari hasil tes pemahaman konsep yang diberikan. Soal tes ini berupa soal kuis (sebanyak satu soal yang diberikan setiap akhir pembelajaran selama 13 kali), soal ulangan tengah semester (UTS) (sebanyak lima soal benar atau salah dan tiga soal uraian) dan soal ulangan akhir semester (UAS) (sebanyak lima soal uraian). Berikut salah satu soal yang diberikan.

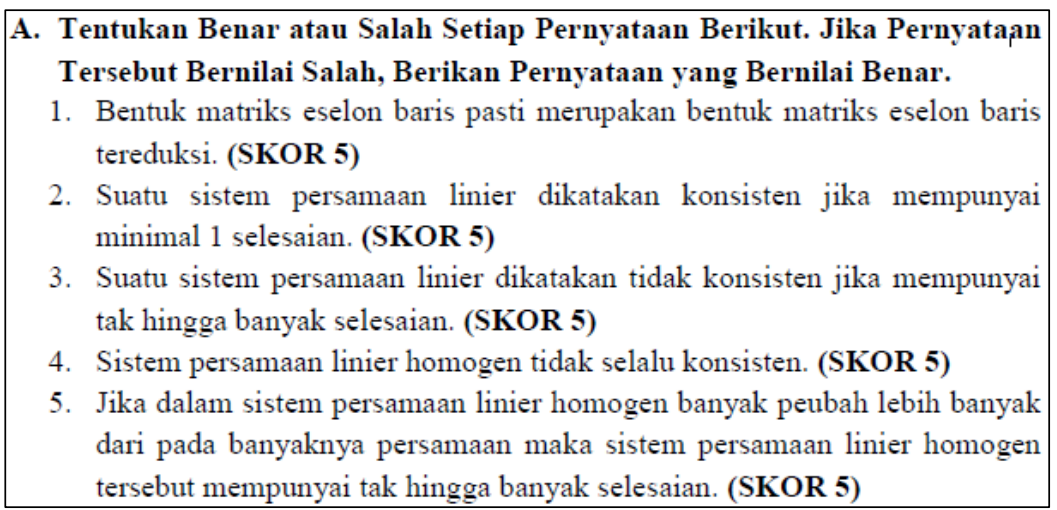

Gambar 5. Salah satu soal untuk menggali pemahaman konsep mahasiswa

Soal pada Gambar 5 merupakan soal bagian A yang diberikan ketika UTS. Untuk soal ini, mahasiswa tidak mengalami kesulitan berarti. Dilihat dari hasil kuis, UTS dan UAS secara keseluruhan, kemampuan pemahaman konsep mahasiswa mengalami peningkatan. Secara keseluruhan dari hasil tes untuk indikator-indikator pemahaman konsep: 1) $87.5 \%$ mahasiswa (14 mahasiswa) dapat menyatakan ulang konsep yang telah dipelajari, (2) 81.25\% mahasiswa (13 mahasiswa) dapat mengklasifikasikan objek-objek, 3) $75 \%$ mahasiswa (12 mahasiswa) dapat menerapkan konsep secara algoritma, dan 4) $81.25 \%$ mahasiswa (13 mahasiswa) dapat memberikan contoh dan bukan contoh dari suatu konsep. Mahasiswa masih belum optimal dalam menerapkan konsep dalam algoritma karena mahasiswa 
kurang teliti dalam langkah-langkah penyelesaiannya. Kesalahan pada proses penyelesaian akan berdampak pada proses berikutnya. Hal ini seperti pekerjaan mahasiswa berikut ini.

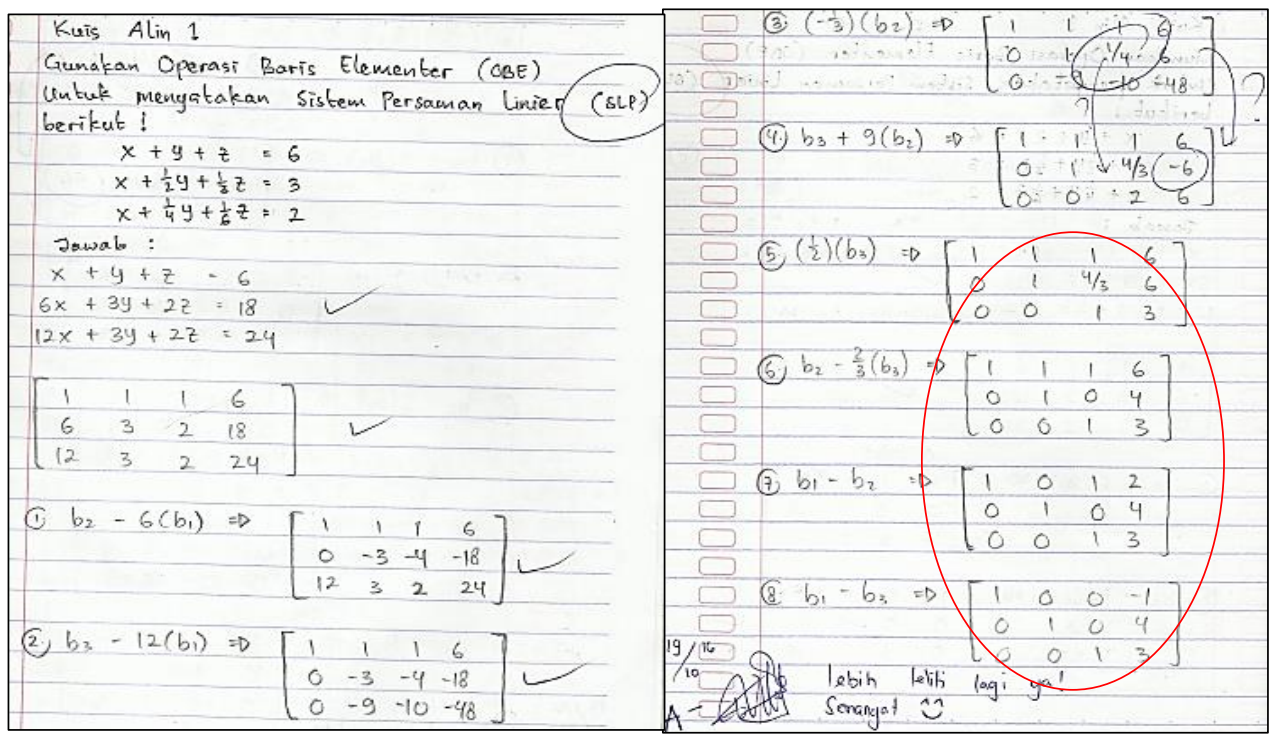

Gambar 6. Salah Satu Hasil Pekerjaan Mahasiswa

Pada Gambar 6 dapat dilihat bahwa mahasiswa kurang teliti dalam melakukan proses penyelesaian yaitu dari langkah ketiga ke langkah keempat tepatnya pada baris kedua. Harusnya entri untuk baris kedua kolom ketiga yaitu $\left(-\frac{4}{3}\right)$ dan untuk baris kedua kolom keempat yaitu $(-2)$. Hasil ini tentu saja berpengaruh pada langkah kelima sampai langkah kedelapan yang juga salah. Selain dari hasil tes, kemampuan pemahaman konsep mahasiswa juga dapat dilihat dari hasil mind mapping yang telah dibuat. Dari hasil mind mapping ini dapat diketahui kemampuan pemahaman konsep mahasiswa terhadap materi secara keseluruhan materi.

\section{Respon mahasiswa terhadap penerapan Concise Learning Method (CLM) dengan mind mapping}

Respon mahasiswa terhadap penerapan Concise Learning Method (CLM) yang diintegrasikan dengan mind mapping pada mata kuliah aljabar linier elementer I dapat dilihat dari hasil angket respon mahasiswa. Angket respon yang diberikan kepada mahasiswa merupakan angket 
terbuka yang menggali data terkait respon mahasiswa terhadap pembelajaran CLM yang diintegrasikan dengan mind mapping. Berdasarkan hasil angket respon diperoleh informasi bahwa mahasiswa memberikan respon positif terhadap pembelajaran CLM yang diintegrasikan dengan mind mapping pada mata kuliah aljabar linier elementer I. Dari 16 mahasiswa, 87.5 \% mengungkapkan bahwa adanya tahap latihan soal (practice) dan kewajiban menulis hasilnya pada buku tugas membuat pemahaman konsep mahasiswa meningkat. Saran yang diberikan mahasiswa yaitu untuk lebih memperbanyak latihan soal.

Sementara itu $93.75 \%$ mahasiswa menyatakan bahwa dengan adanya mind mapping membantu mahasiswa dalam mengingat dan memahami konsep materi-materi mata kuliah aljabar linier elementer secara keseluruhan.

Tahapan pembelajaran CLM yang diintegrasikan dengan mind mapping dapat diuraikan sebagai berikut:

1. Preview (Mempelajari terlebih dahulu materi perkuliahan)

Pada tahap ini mahasiswa diminta untuk mempelajari terlebih dahulu materi yang akan diajarkan oleh dosen, selain membaca dan memahami materi, mahasiswa juga diminta mengerjakan minimal tiga soal dan menyiapkan minimal satu pertanyaan terkait materi yang dipelajari. Tahap ini dilakukan pada pertemuan sebelumnya, hal ini bertujuan agar mahasiswa menjadi tidak asing dengan topik perkuliahan dan menjadi lebih siap mengikuti perkuliahan. Hal ini sebagaimana yang diungkapkan oleh Krasnic (2011b), "The preview phase also prepares your mind for the information to be discussed in the lecture, resulting in increased interest, participation, and comprehension during the lecture." Hal senada juga diungkapkan oleh Orton (2006) bahwa peserta didik belajar matematika dari pengalamannya.

\section{Participate (Berpartisipasi secara aktif dalam perkuliahan)}

Pada tahap ini dosen mendorong mahasiswa terlibat secara aktif selama perkuliahan. Hal ini dilakukan dengan cara membagi mahasiswa menjadi beberapa kelompok, dimana setiap kelompok beranggotakan dua orang. Hal ini sesuai dengan hasil penelitian Benders dan Craft (2016) bahwa belajar dalam kelompok kecil (small student/peer group instruction) dapat memfasilitasi peserta didik dalam meningkatkan 
kemampuan pemahaman dan pencapaian dalam matematika. Dosen menunjuk secara acak salah satu kelompok untuk mempresentasikan materi di depan kelas, sedangkan kelompok yang lain diminta untuk memperhatikan dengan seksama dan mencatat jika ada hal-hal yang ingin ditanyakan terkait penjelasan kelompok yang maju karena setelah presentasi selesai, dosen mewajibkan setiap kelompok untuk mengajukan pendapat, sanggahan atau pertanyaan terkait materi yang disampaikan.

3. Process (Mengolah informasi terkait materi perkuliahan dalam bentuk mind mapping)

Setelah presentasi dan tanya jawab selesai, mahasiswa diminta untuk menghubungkan konsep-konsep yang telah dipelajari. Hal ini dikarenakan konsep materi dalam mata kuliah aljabar linier elementer I saling berkaitan. Hal ini sebagaimana yang diungkapkan Ernest (2004) bahwa konsep dalam matematika tersusun secara hirarki dimana konsep yang satu lebih tinggi daripada konsep yang lain. Konsep satu dengan konsep lainnya dalam mata kuliah aljabar linier elementer I dihubungkan dengan cara membuat mind mapping. Hal ini sebagaimana yang diungkapkan oleh Brinkmann (2003a) bahwa mind maps membantu dalam menghubungkan informasi yang baru dengan pengetahuan yang ada secara bermakna. Dengan mengaitkan pengetahuan yang sudah ada dengan pengetahuan yang baru maka kemampuan pemahaman dan penguasaan konsep mahasiswa juga baik. Sebagaimana tertuang dalam NCTM (2000), ketika peserta didik dapat menghubungkan/mengaitkan ide-ide dalam matematika maka pemahaman mereka akan semakin dalam dan bertahan lama. Selain itu, dengan membuat mind mapping akan membantu mahasiswa untuk mengingat konsep materi dalam jangka waktu lama. Hal ini sebagaimana hasil penelitian Brinkmann (2003a), "mind maps can be used as a memory aid: thus information may be memorized and recalled faster, the learning process is speeded up and information becomes long living."

\section{Practice (Latihan mengerjakan soal)}

Pada tahap ini, dosen mendorong mahasiswa untuk berlatih menyelesaikan soal. Hal ini sebagaimana yang diungkapkan oleh Polya (2004) bahwa belajar menyelesaikan masalah dalam matematika seperti 
belajar berenang, semakin sering kita latihan mengerjakan soal maka kita akan semakin ahli. Dosen juga mengingatkan mahasiswa agar tidak hanya membaca contoh masalah yang solusinya sudah disediakan dan hanya menyelesaikan masalah yang sama dengan contoh yang disediakan, tetapi lebih dari itu mahasiswa diminta untuk mengaplikasikan materi yang sudah dipelajari dalam masalah yang baru (masalah yang tidak diprediksi sebelumnya).

Pada tahap ini, dosen juga menyelipkan beberapa contoh soal ON MIPA PT yang ada hubungannya dengan materi yang dipelajari. Untuk permasalahan-permasalahan yang baru (masalah yang tidak diprediksi sebelumnya), diperlukan campur tangan dosen dalam mengarahkan mahasiswa untuk menemukan solusi dari masalah tersebut. Hal ini didukung pernyataan Hudojo (2005) bahwa diperlukan suatu tuntunan untuk dapat menemukan suatu metode yang dapat digunakan di dalam menyelesaikan suatu masalah.

\section{Produce (Menghasilkan ide baru)}

Pada tahap ini, mahasiswa diminta untuk berpikir secara kritis tentang informasi baru, pertanyaan dan masalah, sehingga dihasilkan pengetahuan yang baru dimana akan terintegrasi dengan baik dengan pengetahuan yang sudah ada. Perlu adanya dorongan, motivasi dan arahan dari dosen untuk membantu mahasiswa dalam menghasilkan ide yang baru. Hal ini sebagaimana yang disampaikan Marzano, Pickering, Arredondo, Blackburn, Brandt, Moffett, Paynter, Pollock, dan Whisler (1997), ketika peserta didik belajar informasi yang baru, mereka harus diarahkan dalam mengelola pengetahuan yang baru tersebut dengan pengetahuan yang ada, mengorganisasikan informasi dan membuat pengetahuan tersebut menjadi bagian dari ingatan jangka panjang mereka.

Kemampuan pemahaman konsep mahasiswa melalui pembelajaran CLM yang diintegrasikan dengan mind mapping secara keseluruhan mengalami peningkatan. Tahapan-tahapan yang terdapat pada CLM yang diintegrasikan dengan mind mapping mampu menfasilitasi mahasiswa dalam meningkatkan kemampuan pemahaman konsep mereka pada materi aljabar linier elementer I. 
Pada awalnya, mayoritas mahasiswa merasa takut ketika mendengar kata aljabar, karena kebanyakan dari mereka menganalogkan dengan pelajaran aljabar waktu SMA. Hal ini sebagaimana yang diungkapkan oleh Jupri, Drijvers dan Heuvel-Panhuizen (2014) bahwa dalam kurikulum matematika, aljabar merupakan materi paling sulit dibandingkan materi matematika lainnya (Jupri, Drijvers \& Heuvel-Panhuizen, 2014). Melalui penerapan CLM yang diintegrasikan dengan mind mapping, mahasiswa memberikan respon yang positif dan termotivasi untuk belajar. Hal ini sesuai dengan hasil penelitian Jones, Ruff, Snyder, Petrich dan Koonce (2012) bahwa aktivitas peserta didik dalam membuat mind mapping dapat memotivasi peserta didik dalam belajar.

\section{Simpulan}

Berdasarkan hasil penelitian dan pembahasan, pembelajaran CLM dengan mind mapping dilaksanakan dengan tahapan sebagai berikut:

1. Preview, pada tahap ini mahasiswa diminta untuk mempelajari terlebih dahulu materi dan mengerjakan minimal tiga soal serta membuat minimal satu pertanyaan terkait materi yang akan dipelajari. Pertanyaan dan hasil pengerjaan mahasiswa ditulis di dalam buku tugas. (Ketentuan ini disampaikan pada pertemuan pertama ketika penyampaian kontrak perkuliahan)

2. Participate, dilakukan dengan cara membagi mahasiswa menjadi beberapa kelompok, dimana setiap kelompok beranggotakan dua orang (pembentukan kelompok dilakukan pada pertemuan pertama waktu penyampaian kontrak kuliah). Pada tahap ini, dosen menunjuk secara acak satu kelompok untuk mempresentasikan materi di depan kelas, sedangkan kelompok yang lain diwajibkan untuk mengajukan pendapat, sanggahan atau pertanyaan terkait materi yang disampaikan.

3. Process, pada tahap ini mahasiswa diminta untuk menghubungkan konsep-konsep yang telah dipelajari dengan cara membuat mind mapping (penjelasan terkait pembuatan mind mapping sudah dipaparkan pada pertemuan pertama waktu penyampaian kontrak kuliah). 
4. Practice, pada tahap ini mahasiswa didorong untuk sering berlatih mengerjakan soal. Sesekali dosen menyelipkan soal-soal ON MIPA PT yang ada kaitannya dengan materi.

5. Produce, pada tahap ini mahasiswa dimotivasi untuk berpikir secara kritis sehingga dapat menghasilkan ide baru terkait materi-materi yang dipelajari.

Kemampuan pemahaman konsep mahasiswa melalui pembelajaran CLM yang diintegrasikan dengan mind mapping mengalami peningkatan, dimana $87.5 \%$ mahasiswa dapat menyatakan ulang konsep yang telah dipelajari, $81.25 \%$ mahasiswa dapat mengklasifikasikan objek-objek, $75 \%$ mahasiswa dapat menerapkan konsep secara algoritma, dan $81.25 \%$ mahasiswa dapat memberikan contoh dan bukan contoh dari suatu konsep

Respon mahasiswa terhadap pembelajaran CLM dengan mind mapping pada mata kuliah aljabar linier elementer I adalah:

1. Mahasiswa merasa senang karena pembelajaran CLM dengan mind mapping membantu mereka dalam belajar materi-materi mata kuliah aljabar linier elementer I dan memudahkan mahasiswa dalam mengingat serta memahami materi secara keseluruhan.

2. Mahasiswa menyukai mata kuliah aljabar linier elementer I yang awalnya mata kuliah ini adalah mata kuliah yang mereka takuti.

Berdasarkan hasil penelitian, berikut saran-saran yang bisa disampaikan:

1. Perlu pemeriksaan lebih lanjut terkait mind mapping yang dibuat mahasiswa, hal ini bisa dilakukan dengan wawancara langsung dengan mahasiswa untuk mengecek dan memastikan materi-materi dalam mind mapping yang dibuat mahasiswa sudah sesuai.

2. Pada tahap keempat yaitu practice, perlu diperhatikan terkait tingkat kesulitan soal yang diberikan, dimana soal harus mampu mengakomodasi kemampuan mahasiswa. Sebaiknya, berikan juga kesempatan pada mahasiswa untuk mengajukan soal sendiri.

3. Pada tahap ke lima yaitu produce, diharapkan ada arahan dari dosen agar mahasiswa benar-benar dapat menghasilkan ide baru. 
4. Perlu dikaji lebih dalam terkait efektivitas penerapan CLM dalam matematika apakah mengintegrasikan CLM dengan mind mapping lebih efektif dibanding CLM sendiri yang di dalamnya sudah memuat visual mapping.

5. Bagi peneliti yang tertarik dengan CLM bisa menerapkan CLM dalam mata kuliah yang lain.

\section{Daftar Pustaka}

Apriyani, D.C.N. (2015). Upaya peningkatan motivasi dan prestasi belajar mahasiswa dengan pembelajaran kooperatif tipe thinking aloud pairs problem solving pada mata kuliah aljabar linier. Beta Jurnal Tadris Matematika, 8(2), 142-152. Diakses di http://jurnalbeta.ac.id/index.php/betaJTM/article/view/31/24

Bender, D. \& Craft, T. (2016). The effect of flexible small groups on math achievement in first grade. Networks: An Online Journal for Teacher Research, 18(1), 1-9. Doi: https://dx.doi.org/10.4148/2470-6353.1022.

Brinkmann, A. (2003a). Graphical knowledge display-mind mapping and concept mapping as efficient tools in mathematics education. Mathematics Education Review, 16(4), 35-48.

Brinkmann, A. (2003b). Mind mapping as a tool in mathematics education. The Mathematics Teacher, 96 (2), 96-101.

Buzan, T. \& Buzan, B. (1994). The Mind map book: How to use radiant thinking to maximize your brain's untapped potential. New York: Dutton.

Ernest, P. (2004). The philosophy of mathematics education. Oxford: Taylor \& Francis.

Hudojo, H. (2005). Pengembangan kurikulum dan pembelajaran matematika (Edisi revisi II). Malang: Universitas Negeri Malang (UM Press).

Jones, B. D., Ruff, C., Snyder J. D., Petrich, B., \& Koonce, C. (2012). The effects of mind mapping activities on students' motivation. International Journal for the Scholarship of Teaching and Learning, 6(1), 1-21.

Jupri, A., Drijvers, P., \& Heuvel-Panhuizen, M.V.D. (2014). Difficulties in initial algebra learning in Indonesia. Mathematics Education Research Journal, 26, 683-710. Doi: http://dx.doi.org/10.1007/s13394-013-0097-0.

Krasnic, T. (2011a). The concise learning method for 21st century students. Diakses di http://www.conciselearning.com/book.html

Krasnic, T. (2011b). How to study with mind maps: The concise learning method. Florida: Concise Books Publishing LLC.

Marsigit. (2012). Kajian penelitian pendidikan matematika. Materi matrikulasi S2 pendidikan matematika. Yogyakarta: PPS Universitas Negeri Yogyakarta. 
Marzano, R. J., Pickering, D. J., Arredondo, D. E., Blackburn, G. J., Brandt, R. S., Moffett, C. A., Paynter, D. E., Pollock, J. E., \& Whisler, J. S. (1997). Dimensions of learning: Trainer's manual (2nd edition). Alexandria: ASCD.

Mustangin \& Debora, A. (2009). Penerapan global learning dan mind mapping dalam pembelajaran matematika sebagai jaringan konsep. Prosiding Seminar Nasional Matematika dan Pendidikan Matematika, Jurusan Pendidikan Matematika FMIPA UNY, 295-309.

NCTM. (2000). Principles and standards for school mathematics. Reston: The National Council of Teachers of Mathematics, Inc.

Nursuprianah, I. \& Sholikhah, M. (2009). Analisis kesulitan mahasiswa dalam memahami mata kuliah aljabar matriks (Studi kasus pada semester IV tadris matematika tahun akademik 2008/2009 di STAIN Cirebon). Jurnal EduMa, 1(1): 75-84. Diakses di https://edumajournal.files.wordpress.com/2011/11/15-analisis-kesulitanmahasiswa-dalam-memahami-by-indah-nursuprianah.pdf

Orton, A. (2006). Learning mathematics: Issues, theory and classroom practice. London: Bloomsbury Academic.

Polya, G. (2004). How to solve It: A new aspect of mathematical method. Princeton: Princeton University Press.

Rosita, C. D, Laelasari, \& Noto, M. S. (2014). Analisis kemampuan pemahaman matematis mahasiswa pada mata kuliah aljabar linier 1. Jurnal Euclid, 1(2): 60-69. Diakses di http://www.fkipunswagati.ac.id/ejournal/index.php/euclid/article/view/53

Spradley, J. P. (2007). Metode etnografi. Yogyakarta: Tiara Kusuma.

Tim Kurikululum. (2015). Pedoman akademik FMIPA Unipdu Jombang. Jombang: FMIPA Unipdu.

Velasco, Q. M. R. \& Joaquin, M. N. B. (2015). Mind mapping with proofblocks: Effects on student geometric level of thinking and mathematics selfefficacy. The $7^{\text {th }}$ ICMI-East Asia Regional Conference on Mathematics Education 11-15 May 2015, Cebu City, Philippines. 525-534. 